\title{
Large-scale biodiversity pattern of Cumacea (Peracarida: Crustacea) in the deep Atlantic
}

\author{
J. D. Gage ${ }^{1, *}$, P. J. D. Lambshead ${ }^{2}$, J. D. D. Bishop ${ }^{3}$, C. T. Stuart ${ }^{4}$, N. S. Jones ${ }^{\text {T }}$ \\ ${ }^{1}$ Dunstaffnage Marine Laboratory, Scottish Association for Marine Science, Oban PA37 1QA, UK \\ ${ }^{2}$ Natural History Museum, Cromwell Road, London SW7 5BD, UK \\ ${ }^{3}$ The Laboratory, Marine Biological Association of the United Kingdom, Plymouth PL1 2PB, UK \\ ${ }^{4}$ Biology Department, University of Massachusetts, 100 Morrissey Boulevard, Boston, Massachusetts 02125, USA
}

\begin{abstract}
Large-scale biodiversity pattern is best known as latitudinal species diversity gradients (LSDGs) on land and may be causally linked to ecological and evolutionary processes influenced by solar insolation. Although similar LSDGs may exist in the sea, patterns are contradictory and not well understood. LSDGs among small benthic taxa in the deep sea are particularly problematic because of sampling and taxonomic limitations, and remoteness from solar-driven processes at the surface. Such explanatory processes are, in any case, likely to be very different from those on land. We investigate large-scale biodiversity pattern in deep-sea benthos by analysis of a data set of 225 species among 55937 individuals of Cumacea identified by the late N. S. Jones from 122 epibenthic sled samples (depth range $\geq 500 \mathrm{~m}$ to $\leq 4000 \mathrm{~m}$ ) mostly taken near the continental margin throughout the deep Atlantic Ocean. Although the plotted data showed considerable scatter, and samples from the South Atlantic were relatively few and extended only to mid-latitudes, they showed a parabolic relationship to latitude, peaking at the equator. Sample diversity from the eastern North Atlantic (62 samples) tended to be higher than that from the western North Atlantic (19 samples), with linear regression relationships of diversity to latitude indicating a poleward decline differing only in elevation of the regression line, although those for the western North Atlantic, like those for the South Atlantic, were not significant. Adding 4 samples from the Nordic Seas as high-latitude end member markedly increased the slope of the regression for the deep eastern North Atlantic. This is consistent with impoverished cumacean diversity in the deep Nordic Seas basins caused by Quaternary extinctions and isolation from the deep Atlantic. Other regional differences in diversity, particularly between the western and eastern North Atlantic, also suggested a strong basin-scale imprint. This underlies the, probably productivity-related, negative relationships between diversity and latitude found, which were similar to those found previously in other deep-sea macrofaunal taxa and Foraminifera. Analysis of the whole Atlantic data set did not support a molluscan-type zoogeographic dispersion from the south into the South and then North Atlantic. Hence, although bathyal LSDG may exist in deep-sea Cumacea, evidence suggests that large-scale pattern may reflect regional history as much as modern ecology.
\end{abstract}

KEY WORDS: Deep sea $\cdot$ Cumacea $\cdot$ Benthos $\cdot$ Latitudinal gradients $\cdot$ Regional diversity

\section{INTRODUCTION}

Large-scale patterns in the diversity of deep-sea organisms are the result of both historical evolutionary and modern ecological processes. These patterns are not well understood and there is still controversy about such basic issues as whether the deep sea has a higher or lower diversity than coastal systems (Gray 1994,
2002, Gage 1996, Gray et al. 1997, Levin et al. 2001, Snelgrove \& Smith 2002, Lambshead \& Boucher 2003), let alone the theoretical explanations of such presumed patterns (Rex et al. 1993, Gray 2003). Examples of studies of such large-sale deep-sea diversity patterns include depth-related (Rex 1981, 1983, Paterson \& Lambshead 1996, Rex et al. 1997, Flach \& de Bruin 1998, Gage et al. 2000) and latitudinal (Rex et al. 1993, 
1997, 2000, Culver \& Buzas 2000, Lambshead et al. 2000, 2002, Mokievsky \& Azovsky 2002) gradients.

While some studies on coastal soft-bottom benthic faunas have failed to demonstrate any clear relationship of diversity to latitude (Gaines \& Lubchenco 1982, Hicks \& Coull 1983, Warwick \& Ruswahyuni 1987, Kendall \& Aschan 1993, Dauvin et al. 1994, Boucher \& Lambshead 1995, Ellingsen \& Gray 2002, Mokievsky \& Azovsky 2002), many others have demonstrated a polewards decline in diversity (Thorson 1957, Fischer 1960, Stehli et al. 1967, Sanders 1969, Roy et al. 1994, Macpherson 2002). Moreover, similar gradients have been described in open-ocean pelagic communities (Reid et al. 1978, Angel 1993, McGowan \& Walker 1993, Dodge \& Marshall 1994, Macpherson 2002). Hillebrand \& Azovsky (2001) pointed out that taxa with a larger body size (e.g. trees and vertebrates) are likely to show a stronger latitudinal diversity gradient than smaller organisms; but this would not explain the variable results for different benthic infaunal taxa.

Latitudinal species diversity gradients (LSDGs) are conspicuous and relatively well-documented features of global biogeography on land and appear as a general polewards decline in species richness across a broad range of taxa (Gaston 2000). Although there has been a variety of explanations, the most promising relate biodiversity to solar energy input, measured as energy, water or water-energy balance (Hawkins et al. 2003, Willig et al. 2003). The processes involved might be simply related to ambient energy-productivity or caused by variable rates of evolution, higher temperatures possibly being associated with faster evolutionary processes (Rohde 1992, Rosenzweig 1995, Roy et al. 1998). However, Bromham \& Cardillo (2003) were unable to find any evidence for a latitudinal link to rate of molecular evolution in an analysis of bird species.

In the shallow sea, dispersal abilities of many marine invertebrates are likely to be greater at low than at high latitudes (Thorson 1950), suggesting a countereffect to speciation arising from isolation. Such causes would not, according to the prevailing paradigms of deep-sea environmental stability and functional isolation from the upper ocean, apply to the deep sea even though this is ultimately nutritionally dependent on the surface ecosystem. This is because temperature in the deep sea is more associated with depth than with latitude, and there is no evidence for latitudinal differences in early life history affecting dispersal.

Yet Rex et al. (1993) unexpectedly reported latitudinal species diversity gradients in samples of molluscs and crustaceans from the deep sea. These taxa showed a polewards decline in diversity (as measured by rarefaction) in the North Atlantic but only for molluscs in the South Atlantic, so they did not fit the classical terrestrial pattern, suggesting a different causal process or processes. Culver \& Buzas (2000) later demonstrated a polewards decline in Foraminifera in both the North and South Atlantic, fitting the classical land pattern. But they related this to climate change from a warm world to an ice world and hence to seasonally fluctuating food supply at higher latitudes for the last 36 million yr rather than to solar-temperature gradients. These authors also noted that the North Atlantic has lower diversity than the South Atlantic for any given latitude and that the deep Nordic Seas areas are especially impoverished, probably owing to geologically more recent glacial episodes.

Lambshead et al. (2000) failed to find a classic latitudinal gradient for marine nematodes in the North Atlantic, but reported a mild positive gradient between $13^{\circ}$ and $56^{\circ} \mathrm{N}$ (but see Rex et al. 2001) that they ascribed to a gradient of increasing surface productivity. These authors also reported that their single Nordic Seas station was noticeably impoverished. Mokievsky \& Azovsky (2002) demonstrated, with additional new data, the generality of the latter observation. Lambshead et al. (2002) reported a negative gradient with latitude in the central northern equatorial Pacific, again positively associated with the gradient of surface productivity.

Rex et al. (1997) and Mokievsky \& Azovsky (2002) set these patterns for macrofauna and nematodes, respectively, in the ecological context of the other large-scale patterns in species diversity in the deep sea, particularly those related to depth. However, the data employed for investigating depth-related control on diversity, like those assembled for fitting latitudinal relationships, show considerable variability. In many cases, apparently parabolic trends peak at differing depths for different taxa and locations in the North Atlantic (Rex 1983, Paterson \& Lambshead 1995, Gage et al. 2000) or instead the gradient is best fitted by a logarithmic relationship (Flach \& de Bruin 1998).

One problem in comparing marine with terrestrial data is that the latter generally employs some measure of regional diversity using species numbers or richness rather than the various ecological diversity indices to estimate alpha (local) diversity that are commonly employed by marine biologists. This is a serious problem because the patterns produced by these different measures can be quite different. For example, alpha diversity measured as rarefaction from deep-sea macrobenthos typically shows about 24 to 56 species present per 100 individuals (Snelgrove \& Smith 2002). This proportion of species to individuals is considerably greater than that found in shallow-water macrobenthos samples, where rarefaction typically indicates much lower diversity. This is simply because population sizes tend to be larger than in deep water as a result of greater productivity rather than because of regional-scale differences in species richness (Gray 
2002). When this is measured from species-area accumulation over large shelf areas in the NW Atlantic, species richness approaches or is comparable to that measured from the adjacent deep sea (Etter \& Mullineaux 2000, Levin et al. 2001), with perhaps even higher levels on the Norwegian and South Australian shelves (Gray et al. 1997). Similarly, comparison of nematodes versus depth measured using a diversity index shows a parabolic curve, with the highest diversity at bathyal and abyssal depths (Boucher \& Lambshead 1995). The same data analysed for regional species richness demonstrates that the shelf has a noticeably higher regional diversity than the deep sea (Lambshead \& Boucher 2003). This is because alpha diversity is influenced by local ecological processes while regional species richness is more influenced by large-scale spatial and long-term temporal events.

Another difficulty is that because gradients of deepsea benthic diversity have generally been interpreted from samples as alpha diversity rather than as regional diversity, there may be high variability of plotted points in relation to the range of the dependent variable. Furthermore, any trend in sample diversity may be difficult to recognise among these noisy data unless the variables, depth and latitude that are dependent in the North Atlantic are controlled.

Because of these difficulties, and because of limited faunal, sampling and geographical coverage and, at least for macrobenthos, almost invariably lack of sufficient replication in quantitative samples, relationships of diversity to latitude, and also depth, remain inadequately explained (Gray 1997, Rex et al. 1997, Lambshead et al. 2000, 2001a).

The 3 major macrobenthic taxa used by Rex et al. (1993) to support their conclusion of an LSDG in the North Atlantic deep sea are groups with large numbers of species (Allen 1978, Wilson \& Hessler 1987). These groups have benefited from expert taxonomic study but, because deep-sea soft sediments are so rich in species, many other speciose groups are less well understood. Available taxonomic effort has been almost overwhelmed by the task of describing the large number of new species encountered (Lambshead 1993). In Rex et al.'s (2000) study, the gastropod sample data set was extended to include zoogeographic records from a comprehensive systematic revision of the highly speciose neogastropod family Turridae undertaken by Bouchet \& Warén (1980). The latter authors incorporated information on geographic range based on 1315 samples, allowing direct comparisons with coastal and terrestrial LSDG studies in which estimates are based on regional richness inventory. The study reinforced the earlier conclusion of a polewards decline in numbers of species in this taxon in the North Atlantic.
Another speciose group among the metazoan benthos in the deep sea is the peracarid crustacean order Cumacea. Deep-sea cumaceans are believed to live partially or completely buried in the top layer of sediment, with many species being surface deposit-feeders or resuspension filter-feeders. Although few species have been investigated, in some, reproductive investment appears timed to coincide with the seasonal arrival of phytodetritus at the seabed (Bishop \& Shalla 1994, Cartes \& Sorbe 1996), suggesting utilisation of this food source. However, a group of nannastacid genera, represented in the current data set by 69 species of Campylaspis, Procampylaspis and Camplyaspides, lack a sieving apparatus, have piercing mouthparts and are thought to be macrophagous, and probably predatory (Jones 1976). Like other peracarids, all cumaceans undergo direct, brooded development. Males undergo a transformation into a final adult instar which is able to swim. This phase occurs in both deepand shallow-water species and is considered to have a dispersive, mate-seeking rôle, with the implication that females are more sedentary. In some bathyal species, movement off the bottom is known predominantly to involve adult males (Cartes \& Sorbe 1997). However, in general all stages can occur in the water column, and on occasions the earliest post-brooding stages (mancas) may predominate in suprabenthic samples (Corbera 2000), suggesting an early dispersive phase. Therefore, dispersal potential of cumaceans appears significant, despite the absence of a true larva.

Large numbers of new cumacean species emerged from extensive new sampling undertaken during the 1960s to 1980s in the deep Atlantic Ocean. The expertise of the late Dr. Norman S. Jones of the Port Erin Marine Laboratory on the Isle of Man was brought to bear on a very large proportion of rich new material belonging to this group (e.g. Jones \& Sanders 1972, Jones 1985). Dr. Jones assembled a data set of 225 species among 55937 individuals of Cumacea from 122 samples taken from a broad latitudinal range in the North and South Atlantic as the basis of a broad zoogeographical analysis which, sadly, was not completed in his lifetime.

As in most previous deep-sea studies (Rex et al. 1993, Culver \& Buzas 2000), our approach is necessarily based on these samples rather than on the regional species inventory often possible in terrestrial and inshore environments: such knowledge of the species composition and distributional range of macrobenthos is at its infancy in the deep sea, even in relatively wellsampled areas. Herein, we consider the pattern revealed by sample-based indices of alpha diversity in relation to other historical and modern influences on large-scale biodiversity pattern in Cumacea, particularly in relation to latitude, in the deep Atlantic Ocean. 
Large-scale pattern is also investigated in relation to regional geography and bathymetric isolation of deepocean basins in the Atlantic, particularly the Nordic Seas. We particularly wished to investigate Gray's (1997) suggestion, countered by Rex et al. (1997), that the depressed diversity in this evolutionarily immature deep-water community of the deep basins of the Nordic Seas solely determines the polewards decline in diversity observed by Rex et al. (1993) in the bathyal North Atlantic.

\section{MATERIALS AND METHODS}

The data considered herein were collected using a towed, bottom-skimming sled-type sampler, with the collecting bag supported by a frame equipped with runners. We have included only samples from devices which we believe operate similarly on the seabed. These include the 'Woods Hole' epibenthic sled used by Woods Hole Oceanographic Institution, the Centre National d'Exploitation des Oceans, CNEXO (now Institute Français pour l'Exploitation de la Mer, IFREMER), and the Scottish Marine Biological Association, SMBA (now Scottish Association for Marine Science, SAMS); the larger epibenthic sledge used by the Institute of Oceanographic Sciences, IOS (now Southampton Oceanography Centre); and the beam trawl, or 'Chalut à perche' also used by CNEXO.

The samples came from depth transects off the continental margin in the North and South Atlantic (Sanders 1969, Jones \& Sanders 1972) and from various subsequent deep-sea campaigns sampling at mainly bathyal to upper abyssal depths, undertaken by French workers on the NO 'Jean Charcot' and 'Thalassa', and British workers mainly on RRS 'Challenger' and RRS 'Discovery' during the 1970s and 1980s.

Lambshead et al. (2000) noted that latitudinal diversity gradients in the deep North Atlantic remain equivocal because the data on which they are based are (1) too sparse, (2) unacceptably clustered because they were collected for other purposes (such as describing change in relation to depth), and (3) subject to additional noise derived from ecological differences between the various basins where the samples were collected. We do not dispute this, but note that the samples we used present no greater problem than those used by Rex et al. (1993). This is because a large amount of the cumacean material used in the present study comes from the same sled samples utilised by these authors. In this respect we feel comparisons between the 2 data sets well justified.

Lambshead et al. (2000) also pointed out that the epibenthic sled samples on which all deep-sea LSDGs, except the core samples of Culver \& Buzas (2000) and
Lambshead et al. $(2000,2002)$ are based, are quantitatively and sometimes qualitatively inadequate. The original epibenthic sled design of Hessler \& Sanders (1967) is able to collect large samples of macrobenthic organisms associated with the sediment surface but, because of dependency on a combination of various operational (Gage 1975, Gage et al. 1980) and designrelated factors such as use of a lengthened cod-end (Gage \& Tyler 1991), catches may be quantitatively and qualitatively variable (Gage et al. 1980). However, differences between catches made by the WHOI epibenthic sled used in most of the sampling and those made by the larger epibenthic sledge (see Rice et al. 1982, Gage \& Tyler 1991) operated by the IOS, and the even larger beam trawl used in some French sampling, yield statistically indistinguishable similar catches in terms of numbers of higher taxa. We have therefore retained all the latter samples in the present study.

The positions of the 122 samples are plotted in Fig. 1, which shows their mostly bathyal/upper abyssal distribution around the edges of the deep Atlantic. Fig. 1 also shows their uneven geographical spread, with the number and latitudinal range of those from the South Atlantic (as in Rex et al.'s 1993 original study) being more restricted than in the North Atlantic. However, compared to Rex et al.'s (1993) data, by including a large number of samples from the Bay of Biscay (Jones 1985) and the Rockall Trough, the present data set provides better resolution of the discontinuity in species richness between the North Atlantic and Nordic Seas noted previously by Rex et al. (1993, 1997), Culver \& Buzas (2000) and Lambshead et al. (2000).

The data spreadsheets were assembled by N.S.J. and were transferred to modern software for the present analyses. Identifications were overwhelmingly by N.S.J., but include other records he regarded as reliable. The bulk of data for the families Leuconidae and Ceratocumatidae was provided by J.D.D.B. Most of the samples yielded large numbers of individuals and would therefore be expected to include a significant fraction of the local species inventory in a macrobenthos community assuming reasonably even distribution of species abundances, as is thought typical in the deep sea (Grassle \& Maciolek 1992). The cumacean data set was predominantly restricted to described species; a small minority were species awaiting description and designated by code letters. Although description of the deep Atlantic cumacean fauna, particularly nannastacids, is relatively well advanced, in some families a substantial number of species await resolution and description, and these species were not included in the data analysed.

The measures of diversity employed are applied to the individual samples. They include the normalised expected number of species, $E\left(S_{\mathrm{n}}\right)$, calculated by 


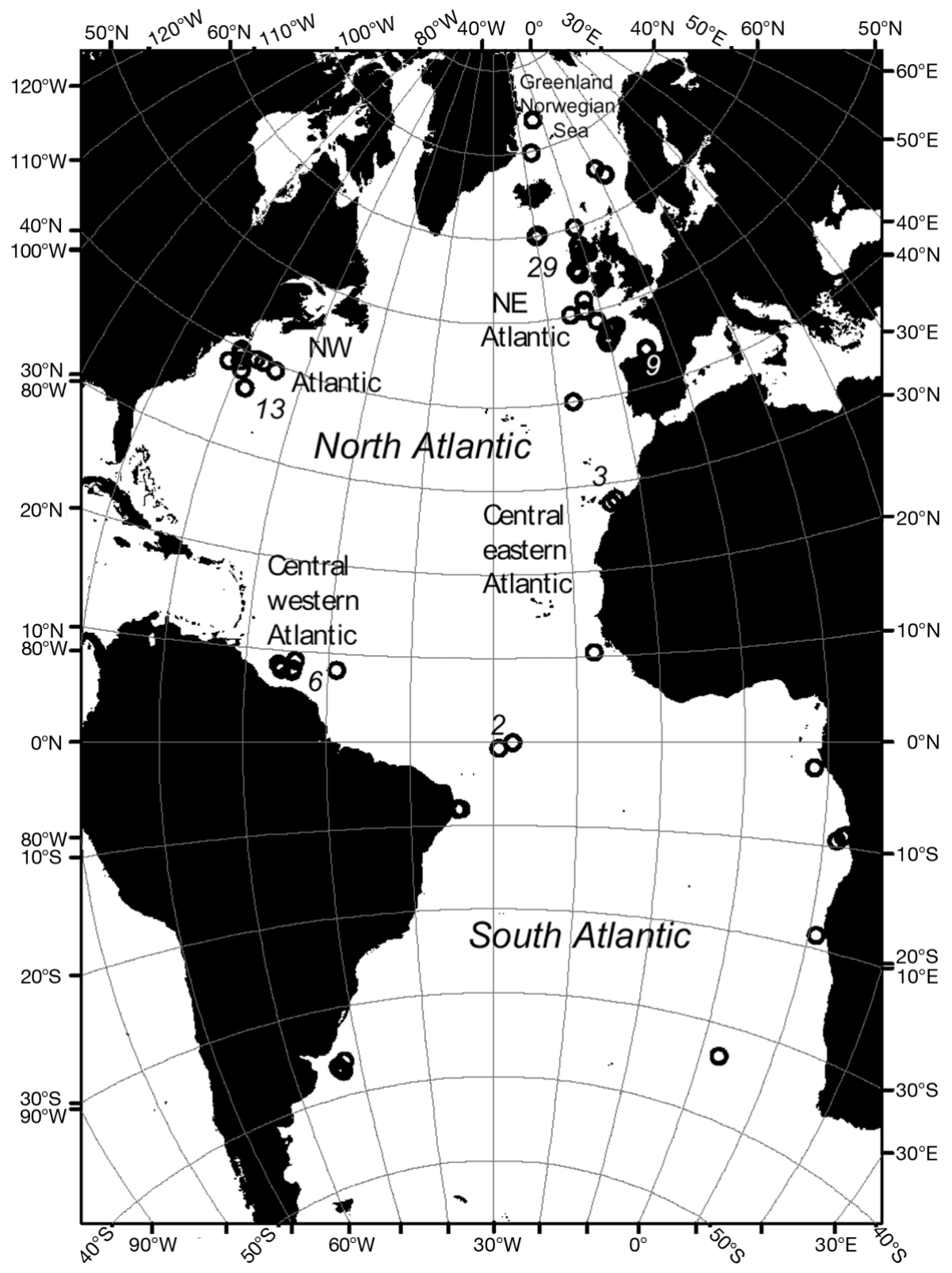

Fig. 1. Regions in North Atlantic Ocean used in analysis and locations of 122 samples used for diversity comparisons. Numerals denote numbers in closely grouped locations
Seas were monospecific, so the more usual measure Pielou's $J^{\prime}$ could not be calculated. However, the simple Berger-Parker index has elsewhere proved surprisingly useful (Shaw et al. 1983). References and formulation of these statistics are provided in Magurran (1988). Ecological diversity indices such as $E\left(S_{\mathrm{n}}\right)$ and $H^{\prime}$, and especially $d$, are far from ideal tools for investigating large-scale diversity patterns such as LSDGs (Rowe 1980, Boucher \& Lambshead 1995, Lambshead et al. 2000) but are employed here in addition to species richness to make our work easily comparable with previous studies.

We applied linear regression analysis to hemispheric investigation of diversity relationships to latitude and other variables in order to provide comparability with previous studies. To control for the effect of depth, analysis of residuals by regression of residuals of the relationships between diversity versus depth and latitude versus depth was applied. Stepwise multiple regression was also employed to investigate the influence of other possible variables, including depth, as predictors of diversity.

Comparisons based on basinscale geographical regions chosen to reflect the geographical aggregation of sampling were made by analysis of similarities, ANOSIM (Clarke 1993), using the PRIMER (Plymouth routines in multivariate ecological research) v. 5 computer package. This allowed us to test for similarities within and between regions taking the regional sam- rarefaction using Hurlbert's (1971) formulation, and Shannon's $H^{\prime}$ (using $\log _{2}$ ). It should be noted that in common with most indices of diversity, $E\left(S_{\mathrm{n}}\right)$ and $H^{\prime}$ embody a weighting of species richness $S$ (the number of species present) by the relative abundances, or evenness in their numerical representation. Evenness is measured here separately as the reciprocal, $1 / d$, of the Berger-Parker statistic $d$, which is simply the percent abundance of the commonest species, sometimes known as Rank 1 dominance. This was employed because some relatively large samples from the Nordic ples as replicates. ANOSIM is a multivariate randomisation-testing procedure using rank similarities that is broadly analogous to ANOVA. The output statistic $R$ is first computed to test for differences between regions (global test), with the value $>0$ reflecting the degree of separation between them. In order to determine where and to what extent regional differences are expressed, the statistic is then re-computed under permutations of the samples to test the null hypothesis that their region of origin is irrelevant. $R$ takes the value of 0 if similarities between and within regions are the same on aver- 
age and 1 if all samples within a region are more similar to each other than to any samples from different regions.

Regional diversity was estimated for (1) the entire data set, (2) the entire eastern Atlantic, (3) the entire western Atlantic, (4) the eastern North Atlantic (from approx. $44^{\circ}$ to $60^{\circ} \mathrm{N}$ ), (5) the western North Atlantic (from approx. $38^{\circ}$ to $40^{\circ} \mathrm{N}$ ), and (6) the central western Atlantic (from approx. $1^{\circ} \mathrm{S}$ to $9^{\circ} \mathrm{N}$ ). The Nordic Seas fauna contained too few species to estimate regional diversity, and the central eastern Atlantic too few samples. Regional species richness at this basin scale was calculated using asymptotic richness estimators. First, 'species per sample' accumulation curves were plotted against abundance as recommended by Gotelli \& Colwell (2001), with order of sample input randomised 50 times to remove distortions derived from local ecology. Colwell's EstimateS program (R. K. Colwell [1997] EstimateS: statistical estimation of species richness and shared species from samples, Version 5-user's guide and application published at: http://viceroy.eeb.uconn.edu/estimates) was used for this purpose. The sigmoidal growth model $\left[y=\left(a b+c x^{d}\right) /\left(b+x^{d}\right)\right]$ was fitted to the resulting curves using the shareware CurveExpert program to establish an asymptote. Second, the non-parametric incidence-based coverage estimator, ICE (Lee \& Chao 1994), was employed because this is reasonably robust to inadequate sampling and patchiness in the data (Chazdon et al. 1998). When the sample coverage estimate $(C)$ is the proportion of all individuals in infrequent species that are not uniques, then the ICE estimator of species richness $(S)$ is:

$$
S_{\text {ice }}=S_{\text {freq }}+\frac{S_{\text {infr }}}{C_{\text {ice }}}+\frac{Q_{1}}{C_{\text {ice }}} \gamma_{\text {ice }}^{2}
$$

where $\gamma_{\text {ice }}^{2}$, which estimates the coefficient of variation of the $Q_{j} S$, is

$$
\gamma_{\text {ice }}^{2}=\max \left[\frac{S_{\text {infr }}}{C_{\text {ice }}} \frac{m_{\text {infr }}}{\left(m_{\text {infr-1 }}\right)} \frac{\sum_{j=1}^{10} j(j-1) Q_{j}}{\left(N_{\text {infr }}\right)^{2}}-1.0\right]
$$

where $Q_{1}$ is the frequency of uniques and $Q_{j}$ is the numbber of species that occur in exactly $j$ samples and $m$ is the number of samples, and $N$ is the number of occurrences. Colwell's EstimateS program was again used for calculations.

To provide insight into regional endemism, the numbers of species unique to the 5 regions was estimated simply as the number actually observed in the entire region in relation to the number actually observed from the samples as a proportion of the entire region.
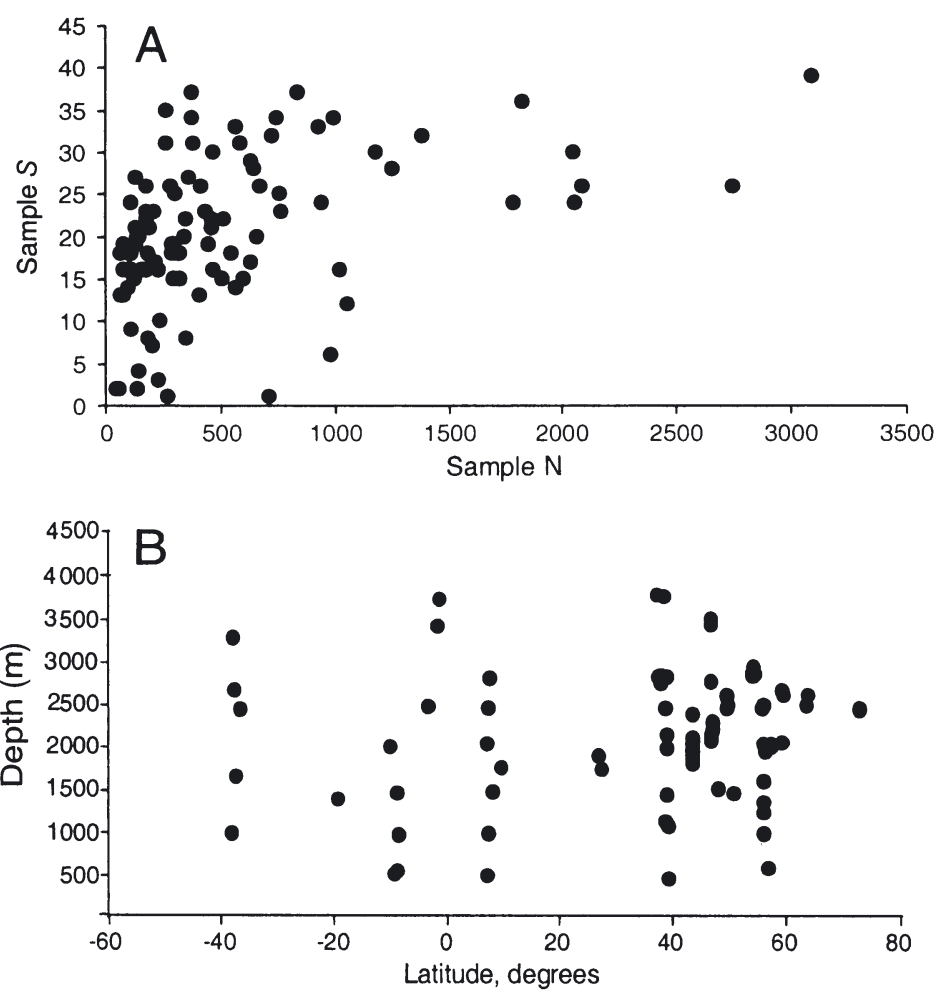

Fig. 2. Variability in sample characteristics. (A) Species richness $(S)$ versus total sample size $(\mathrm{N})$; $(\mathrm{B})$ sample depth plotted against latitude

\section{RESULTS}

Representation of local biodiversity as sampled by the swath of an epibenthic sled would be expected to be reasonably complete, provided that a large enough number of individuals had been taken. This is confirmed by a plot of the number of cumacean species, $S$, in the sample versus sample $N$, the total number of individuals present. Although showing high variability, $S$ rises steeply upwards in the range $\mathrm{N}=0$ to 50 , thereafter quickly flattening out as a decaying exponential curve (Fig. 2A). Because of this marked sample-size dependency of $S$ in small samples, those with $\mathrm{N}<50$ were eliminated from the comparison. Further, to allow comparison with Rex et al.'s $(1993,1997,2000)$ data, the data set was limited to samples from depths $\geq 500 \mathrm{~m}$ to $\leq 4000 \mathrm{~m}$ to restrict the analysis to depths of the continental slope and rise. In conjunction with restriction to epibenthic sled type samples, this left a total of 100 samples and 208 species for analysis.

Sample depth plotted against latitude remained variable, but with no obvious polewards trend within the restricted depth range (Fig. 2B).

Species diversity as $E\left(S_{50}\right)$, calculated by rarefaction, and Shannon's $H^{\prime}$ were measured for each sample. Values were highly variable, but when plotted against 

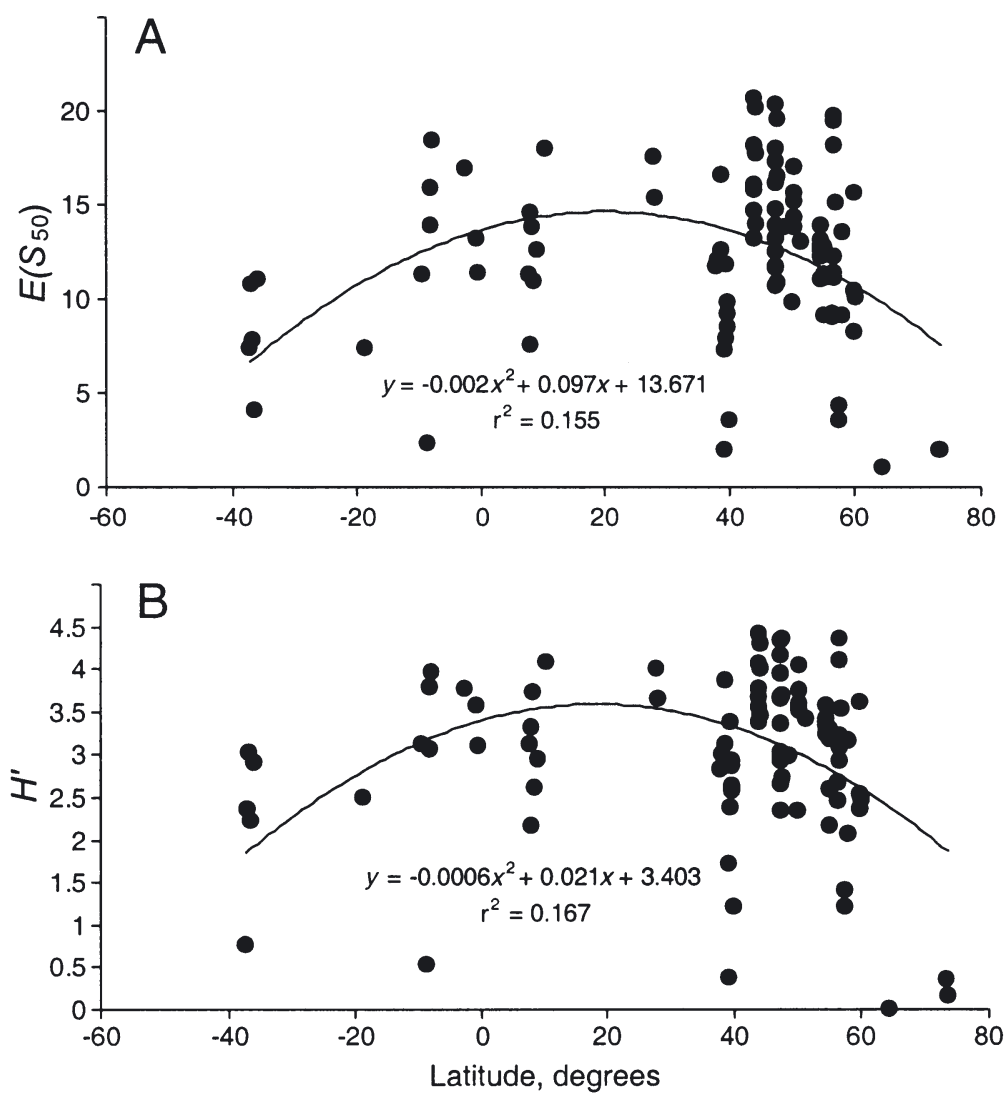

Fig. 3. Diversity as a function of latitude for entire data set (southern and northern hemispheres) with fitted second-order polynomial regressions and equation. (A) Hurlbert's expected number of species (rarefaction) for $\mathrm{N}=50, E\left(S_{50}\right)$; (B) Shannon's $H^{\prime}$

latitude a parabolic relationship was suggested, peaking at low latitudes with levels dropping at higher latitudes, particularly in the North Atlantic (Fig. 3).

We decided against a unified investigation of relationships in the North and South Atlantic together because of the considerable disparity in numbers of samples available, with also much more limited latitudinal coverage in the South compared to the North Atlantic. Fitted linear regression relationships of diversity to latitude for the South Atlantic samples considered separately (14 samples) were not significant. We therefore took only the data from the North Atlantic (88 samples) for further investigation of biodiversity pattern in relation to latitude.

We first plot sample $\mathrm{N}$ versus latitude, the highly variable data showing only a very weak trend to increase polewards (Fig. 4). We next investigated the relationship of sample diversity statistics $E\left(S_{50}\right)$ and $H^{\prime}$ and also species richness, $S$, and sample evenness as Berger-Parker
$1 / d$, to latitude. Fitted parameters of linear regressions, along with analysis of residuals in order to remove the possibly confounding effect of depth, are given in Table 1 . These showed no significant relationship of $E\left(S_{50}\right)$ and only a weak relationship of $H^{\prime}$ to latitude. The similarity of these latter regression relationships (listed under 'Depth removed' in Table 1) with the previous ones indicates that depth had not influenced the results. This result was confirmed by forward stepwise multiple regression results with diversity as dependent variable, and latitude, longitude, depth and depth squared (in order to transform possibly non-linear diversity/depth relationships). For both $E\left(S_{50}\right)$ and $H^{\prime}$ all variables were eliminated.

Despite high variability, diversity plotted by region (Fig. 5) strongly suggested differing, though overlapping, trends for the eastern North Atlantic compared to the western North Atlantic. This indicated that regional-scale differences may occur as well as biodiversity pattern related to latitude. Because of this, and the wide geographic separation of these 2 sets of bathyal samples from the NE and NW Atlantic, we investigated diversity-latitude relationships on the 2 sides of the North Atlantic separately.

Fitted linear regressions are shown plotted separately in Fig. 5 for the eastern and western North Atlantic. Because of their much closer geographical proximity to the eastern rather than the western North Atlantic the 4 samples from the Nordic Seas are included with the former samples. For both $E\left(S_{50}\right)$ and $H^{\prime}$ there was a highly significant negative relationship for the eastern North Atlantic samples, indicating poleward de-

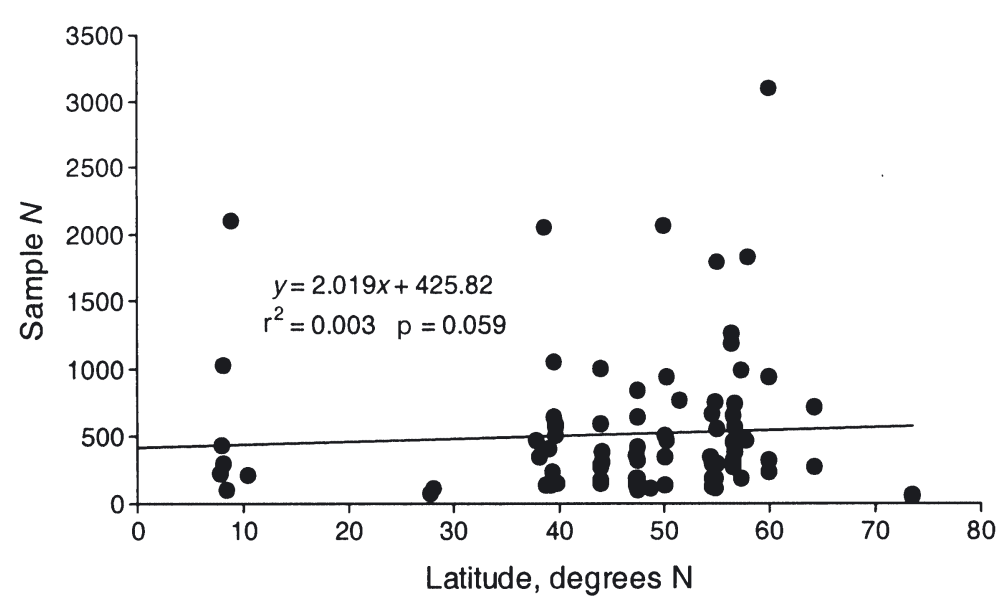

Fig. 4. Sample N versus latitude in North Atlantic with fitted linear regression (restricted data set only— see 'Results') 
Table 1. Entire North Atlantic: results of linear regressions of species diversity as $E\left(S_{50}\right)$ and $H^{\prime}$ species richness $S$, and evenness as Berger-Parker $1 / d$, on latitude with ('Depth removed') analysis of residuals to remove effect of depth. Sample $\mathrm{N}=88$. Non-significant regression equations not shown

\begin{tabular}{|lcccc|}
\hline Diversity statistic & Regression equation & $\mathrm{r}^{2}$ & $F$ & $\mathrm{p}$ \\
\hline$E\left(S_{50}\right)$ & - & 0.032 & 2.843 & 0.095 \\
$H^{\prime}$ & $y=-0.0149 x+3.712$ & 0.055 & 5.023 & 0.028 \\
$S$ & - & $>0.001$ & 0.009 & 0.925 \\
Berger-Parker 1/d & $y=-0.0426 x+5.660$ & 0.107 & 10.281 & 0.001 \\
Depth removed & & & & \\
$E\left(S_{50}\right)$ & - & 0.035 & 3.112 & 0.081 \\
$H^{\prime}$ & $y=-0.0154 x$ & 0.059 & 5.437 & 0.022 \\
$S$ & - & $>0.0001$ & 0.004 & 0.950 \\
Berger-Parker 1/d & $y=-0.0445 x+2.0251$ & 0.116 & 11.251 & 0.001 \\
\hline
\end{tabular}

Table 2. Linear regressions for eastern and western North Atlantic considered separately (but note that both include the 2 samples taken at equator; see Fig. 1). Non-significant regression equations not shown

\begin{tabular}{|lccrc|}
\hline Diversity statistic & Regression equation & $\mathrm{r}^{2}$ & $F$ & $\mathrm{p}$ \\
\hline Eastern North Atlantic only $(\mathrm{N}=68)$ & & & \\
$E\left(S_{50}\right)$ & $y=-0.149 x+20.441$ & 0.175 & 14.24 & 0.0003 \\
$H^{\prime}$ & $y=-0.036 x+4.933$ & 0.206 & 17.336 & $<0.0001$ \\
$S$ & - & 0.024 & 1.639 & 0.205 \\
Berger-Parker 1/d & $y=-0.0803 x+7.751$ & 0.256 & 23.003 & $<0.0001$ \\
\multicolumn{5}{c}{ Eastern North Atlantic with Nordic Seas excluded $(\mathrm{N}=62)$} \\
$E\left(S_{50}\right)$ & $y=-0.0763 x+17.417$ & 0.066 & 4.421 & 0.039 \\
$H^{\prime}$ & $y=-0.0165 x+4.120$ & 0.082 & 5.646 & 0.021 \\
$S$ & - & 0.008 & 0.524 & 0.472 \\
Berger-Parker 1/d & $y=-0.071 x+7.357$ & 0.190 & 14.817 & 0.0003 \\
Western North Atlantic only $(\mathrm{N}=21)$ & & & \\
$E\left(S_{50}\right)$ & - & 0.140 & 3.095 & 0.095 \\
$H^{\prime}$ & - & 0.121 & 2.598 & 0.123 \\
$S$ & - & 0.061 & 1.231 & 0.281 \\
Berger-Parker 1/d & - & 0.082 & 1.707 & 0.207 \\
\hline
\end{tabular}

Table 3. R-values (\% significance level in parentheses) from analysis of similarities (ANOSIM) based on Bray-Curtis similarities of 4th-root-transformed species abundances of regions in North Atlantic

\begin{tabular}{|lrrrr|}
\hline \multirow{2}{*}{$\begin{array}{l}\text { Pairwise tests } \\
\text { of regions }\end{array}$} & Nordic Seas & \multicolumn{4}{c|}{ Atlantic } & \\
\cline { 3 - 5 } & & & NW & Central W \\
Nordic Seas & & & & \\
NW Atlantic & $0.73(0.1)$ & & & \\
NE Atlantic & $0.979(0.1)$ & $0.533(0.1)$ & & \\
Central W Atlantic & $0.927(0.1)$ & $0.36(1.2)$ & $0.725(0.1)$ & \\
Central E Atlantic & $1.0(0.8)$ & $0.352(5.7)$ & $0.79(0.2)$ & $0.0(45.2)$ \\
Global test & $0.721(0.1)$ & & & \\
\end{tabular}

cline of diversity with increasing latitude (Fig. 5A,B). However, inspection of the very low values for the 4 samples from the Nordic Seas (grey squares on extreme right of Fig. 5) suggests that these points would have considerably influenced the downwards slope with increasing latitude. When these samples were removed from the regression for the eastern North Atlantic, however, weakly significant negative relationships of $E\left(S_{50}\right)(\mathrm{p}=0.031)$ and $H^{\prime}$ $(\mathrm{p}=0.021)$ to latitude remained. However, there was no significant negative relationship of species richness $(S)$ to latitude in the eastern North Atlantic either with or without these 4 samples (Fig. 5C, Table 2). Furthermore, in a forward stepwise multiple regression with $S$ as dependent variable, all independent variables except sample $\mathrm{N}$ ( $p<0.001)$ were eliminated as significant predictors.

For the western North Atlantic, linear regressions of diversity as $E\left(S_{50}\right)$ and $H^{\prime}$ to latitude showed slopes similar to those for the eastern North Atlantic with the Nordic Seas removed (Fig. 5), although none of the relationships were significant (Table 2).

Latitude-related differences in evenness, plotted as the Berger-Parker 1/d, were also tested for the eastern North Atlantic data with and without the Nordic Seas samples, both linear regressions (Fig. 5D, Table 2) showing significant and similar polewards decline. This indicates that, unlike $E\left(S_{50}\right)$ and $H^{\prime}$, elimination of the samples from the Nordic Seas had little effect on this latitudinal trend. In forward stepwise multiple regression, latitude and $\mathrm{N}$ emerged as the only significant (both $\mathrm{p}<0.001$ ) predictors for $1 / d$ only when the Arctic samples were included, while only latitude remained significant after the Nordic Seas samples were removed.

The result of testing for differences between regions in relation to that between their component samples showed the greatest regional differences (highest values of ANOSIM $R$ ) between the Nordic Seas compared to other regions (Table 3), although the 

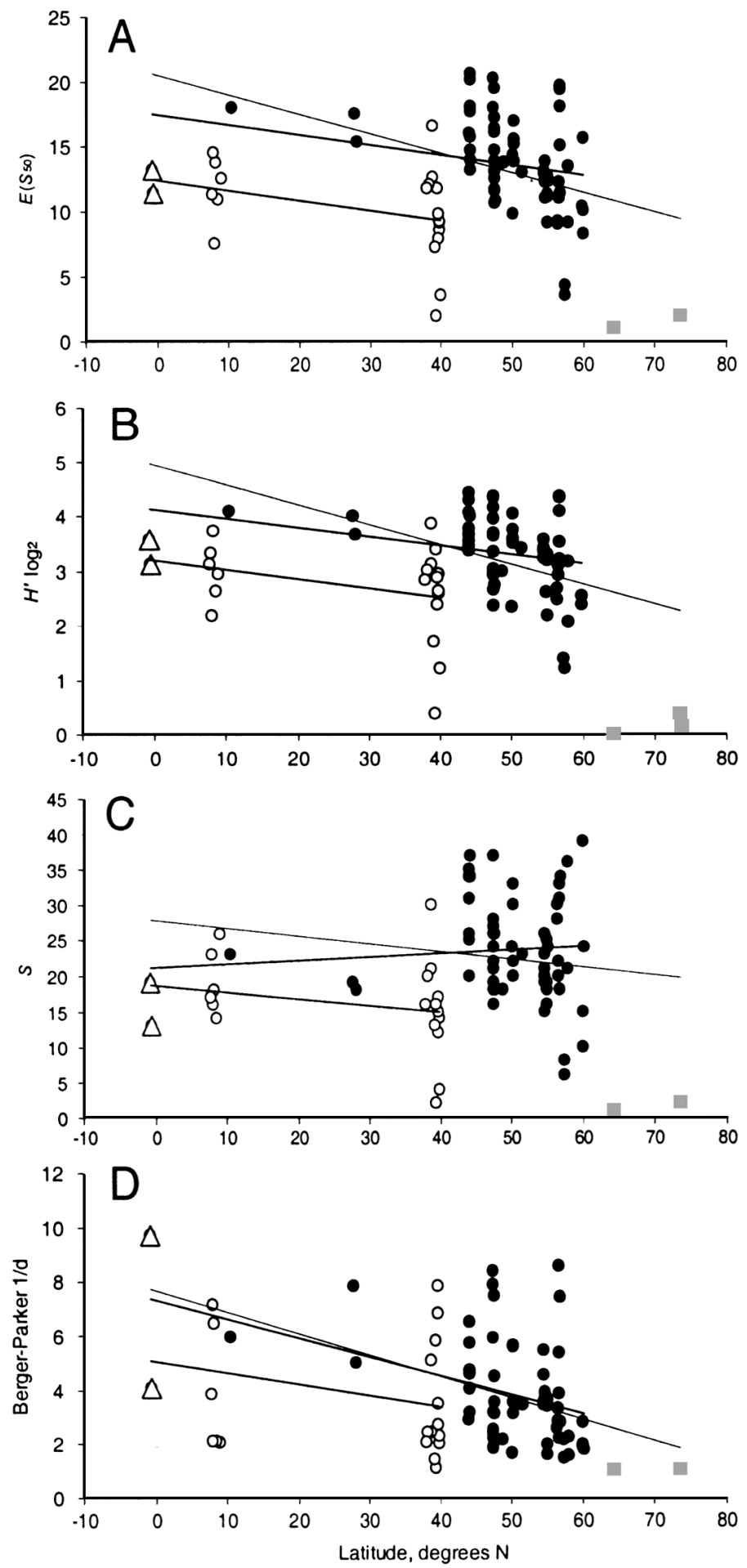

Fig. 5. Restricted data set: diversity as a function of latitude; plots with fitted linear regressions for samples from western North Atlantic $(O$, lower line) and eastern North Atlantic (๑) upper 2 lines) plotted separately, with samples including (long lines) and excluding (short lines) samples from Nordic Seas $(\square)$. Samples $(2, \Delta)$ taken close to the equator off $S$ America are included with those from western North Atlantic. (A) $E\left(S_{50}\right)$; (B) Shannon's $H^{\prime}$; (C) species richness, $S_{\text {; }}$ (D) Berger-Parker measure of evenness, 1/d
Table 4. Regional cumacean species richness estimated by curve fit and non-parametric ICE for all data and for subregions excluding the Arctic (see 'Results' for details). N: no. of samples; ICE: incidence-based coverage estimator

\begin{tabular}{|lrccr|}
\hline Region & N & Curve fit & $\begin{array}{c}\text { R of } \\
\text { curve fit }\end{array}$ & ICE \\
\hline All data & 90 & 284 & 0.9993 & 223 \\
E Atlantic & 63 & 243 & 0.9993 & 159 \\
W Atlantic & 19 & 234 & 0.9999 & 139 \\
NE Atlantic & 60 & 174 & 0.9995 & 142 \\
NW Atlantic & 12 & 100 & 0.9993 & 83 \\
Central W Atlantic & 8 & 200 & 0.9999 & 97 \\
\hline
\end{tabular}

Table 5. Number of species in data unique to 5 regions. Expected number of unique species calculated from proportion of samples from each region. Samples from Nordic Seas included 3 with low total abundance which were excluded from regression analyses. N: no. of species

\begin{tabular}{|lrcc|}
\hline Region & N & \multicolumn{2}{c|}{$\begin{array}{c}\text { Unique species } \\
\text { observed }\end{array}$} \\
\hline Nordic Seas & 7 & 0 & 6 \\
NE Atlantic & 60 & 43 & 48 \\
NW Atlantic & 12 & 11 & 9 \\
Central E Atlantic & 3 & 14 & 2 \\
Central W Atlantic & 8 & 3 & 6 \\
Totals & 90 & 71 & 71 \\
\hline
\end{tabular}

pair-wise test with the NW Atlantic indicated more similarity than with the remainder, including the NE Atlantic. The pair-wise tests also indicate, relatively low similarity between the NE Atlantic and the central Western Atlantic and central Eastern Atlantic regions, while similarity was greatest between the latter 2 regions.

We further investigated differences in cumacean diversity pattern at the regional scale in the deep Atlantic by means of asymptotic richness estimators. In general there was rather poor agreement between the patterns produced by ICE and the curve fit (Table 4), with the ICE estimate in every case falling substantially below that from the curve fit. Also, the ICE estimates for the eastern and western Atlantic were substantially lower (around 50\%) than for the whole data set. Table 5 shows the number of species that were unique to samples from each region and the number of unique species predicted assuming that this is solely the result of sampling intensity.

\section{DISCUSSION}

There have been 2 main causes put forward to explain large-scale diversity pattern in the deep sea: productivity and disturbance, and evolutionary history. 


\section{Productivity and disturbance}

Rosenzweig \& Abramsky (1993) argued that a humpshaped response of diversity to productivity operates in many taxa (see also reviews by Abrams 1995, Waide et al. 1999 and Mittelbach et al. 2001). Areas of high enrichment with concomitantly depressed diversity in the deep sea include oxygen minima impinging on the bathyal (Levin \& Gage 1998), areas of upwelling (Sanders 1969), deep ocean trenches (Jumars \& Hessler 1976), canyons (Gage et al. 1995, Vetter \& Dayton 1998), and bottom areas subjected to episodic erosive currents (benthic storms) driven by surface-originating vorticity that increases nutrient availability to benthic organisms (Thistle et al. 1985, Aller 1997). Historical deposition of a superficial turbidite has been suggested to have caused a lasting disturbance depressing both macro- and meiofaunal diversity (Glover et al. 2001 and Lambshead et al. 2001b, respectively). It therefore has yet to be demonstrated (with the possible exception of upwelling zones) that any area in the food-limited deep sea experiences a sufficiently high food supply to cause, in itself, a decrease in diversity.

Lambshead et al. (2000) regarded the broad-scale increase in productivity with increasing latitude in the North Atlantic (which will affect the benthos as sinking detrital food) as responsible for a positive LSDG in nematodes observed outside the Nordic Seas. Lambshead et al. (2002) reported a similar productivity-based relationship to sample richness in the central Pacific. Unfortunately, the present sample data were essentially non-quantitative and thus not well-suited to testing whether increasing faunal densities themselves result in increasing species richness in samples with increasing latitude. However, no such clear increase in sample N was apparent (Fig. 4).

Rex et al. (2000) suggested that the increasingly seasonal delivery of organic enrichment provides the most plausible explanation for diversity decreasing polewards (negative LSDGs) at the ecological timescale. The trend for decreasing evenness, measured as Berger-Parker $1 / d$, in cumaceans (Fig. 5D) is consistent with this explanation for the reasons explained below. It is apparent whether the Nordic Seas samples are included or not (Table 1), and whether the western and eastern North Atlantic data are considered together or separately, although the trend is not significant for the western North Atlantic samples (Table 2). Some bathyal cumaceans show a reproductive response to seasonally pulsed fluxes of organic material to the seabed (Bishop \& Shalla 1994, Cartes \& Sorbe 1996). It follows that utilisation of this material may also fuel population expansion among these cumaceans similar to the way in which it increases abundance among foraminiferan phytodetritus opportunists. In the latter, numerical dominance of these species increases, reducing assemblage evenness and therefore also alpha (sample) diversity (Gooday 1988, Gooday \& Lambshead 1989, Lambshead \& Gooday 1990). Culver \& Buzas (2000) linked this to the observed strongly negative LSDG in this taxon. We suggest that the observed trend to decreasing evenness, and hence lower diversity, of cumaceans at increasingly higher latitudes reflects higher population abundances of phytodetritus-consuming species responding to the increasing northwards intensity of this seasonal signal.

\section{Evolutionary history}

The link of such ecological causation to the historical dimension, which may be at least as important as modern-day ecological processes (Rex et al. 1997, Lambshead et al. 2000), is the development of LSDGs in benthic Foraminifera. LSDGs are thought to be related to the onset of seasonal production which coincided with global cooling in the early Cenozoic 36 million yr ago through an increase in the numbers of opportunistic, phytodetritus-exploiting species at higher latitudes (Thomas \& Gooday 1996).

Causation of LSDG by historical processes dates back to the study of Wallace (1878) who thought that the high species richness and 'mature' biodiversity of tropical low latitudes on land is an expression of uninterrupted evolution, contrasting with higher latitudes where climatic change has been greatest, resulting in periodic checks and extinctions. Wilson (1998) stressed how such regional pattern in the colonisation history of the deep sea might result in latitudinal trends, while Rex et al. (1993) stressed the possible importance of history in explaining biodiversity patterns at the regional as well as on a larger scale. For example, environmental instabilities caused by Heinrich events (massive discharges of icebergs into the North Atlantic Ocean) over the last 100000 yr (Bond \& Lotti 1995) may have affected regional deep-sea benthic biodiversity. Cronin \& Raymo (1997) showed that fluctuations in deep-sea benthic ostracod diversity in the North Atlantic during the Pliocene were clearly related to glacial retreat and advance. A similar depressing effect during glacial advance affecting surface production might explain the clear difference in the pattern of cumacean diversity between the NW and NE Atlantic, because Quaternary glaciation penetrated further south in North America than in northern Europe (Lowe \& Walker 1997).

The influence of such climatic change impacting deep-sea benthic diversity, as observed by Cronin \& Raymo (1997), demonstrates both large-scale and relatively rapid responses of the benthic community to 
climate-driven changes in either thermohaline circulation, bottom-water temperature (including factors related to temperature) or/and food. Such responses serve to show the coupling of patterns in deep-sea benthic diversity to surface productivity that also seems to be reflected in the patterns so far observed in deep-sea macro- and meiofaunal taxa discussed above.

However, despite the observed trend towards declining cumacean diversity in the limited data from the South Atlantic to $\sim 38^{\circ} \mathrm{S}$, the biodiversity pattern of the deep North Atlantic does not easily translate to the southern hemisphere. Here, although data remain relatively sparse compared to the northern hemisphere, sample diversity of macrobenthic species seems to remain remarkably high into at least moderately high latitudes (Poore \& Wilson 1993). Wilson (1998) argued that 2 factors have caused greater diversity in the South than in the North Atlantic. The first is the continuity of the South Atlantic with adjacent oceans, while the North Atlantic has only contact with the South Atlantic. Such continutity allows greater scope for immigration of species from a wider species pool than that subject to extinctions. The second is that rapid shifts in oceanographic conditions driven by warm/cold oscillations within glaciations of the larger cycles of Quatenary glacial retreat and advance have occurred in the North Atlantic. For the Nordic Seas, the massive disturbance caused by the Storegga slide starting 30000 to $50000 \mathrm{yr}$ BP might also be added. This slide, one of the world's largest, with the last major phase of disturbance occurring 6000 to 8000 yr BP (Bugge et al. 1988), may have caused basin-scale extinctions in the deep Nordic Seas. Furthermore, because of the isolation of its deep-water mass by submarine sills, recolonisation of the ArcticNordic Seas has come from shallow waters rather than from the North Atlantic. Also the relatively short period available for recolonisation would tend to cause its biodiversity to be still impoverished compared to other Atlantic deep-sea basins (Dahl 1972, Svavarsson et al. 1993). From this historical perspective south of these sills, a step-like increase in diversity into the North Atlantic would be expected. The finding of basin-scale differences in diversity in the eastern versus the western North Atlantic imprinted on a weakly negative latitudinal gradient suggests asymmetry in Quaternary effects on bathyal diversity occurring on the 2 sides of the North Atlantic, possibly caused by the pattern of thermohaline circulation.

A much more gradual decrease occurring from the South to North Atlantic as a result of a 'peninsular' effect (Wilson 1998) might also be expected, assuming constant rates of in-place speciation and immigration into the South Atlantic from the contiguous oceans beyond South America and South Africa. However,
Table 6. Regional diversity statistics (see 'Materials and methods' for limits of regions listed below). Pielou's $J^{\prime}$ is a measure of evenness of species abundances and is applied rather than BergerParker index because the samples are pooled

\begin{tabular}{|lrrccc|}
\hline Region & $S$ & Total N & Pielou's $J^{\prime}$ & $E\left(S_{50}\right)$ & $H^{\prime}$ \\
\hline S Atlantic & 93 & 6364 & 0.67 & 20.41 & 4.401 \\
Central W Atlantic & 66 & 4586 & 0.75 & 21.13 & 4.447 \\
Central E Atlantic & 44 & 395 & 0.91 & 25.41 & 4.973 \\
W Atlantic & 110 & 11933 & 0.778 & 26.29 & 5.279 \\
E Atlantic & 140 & 35001 & 0.757 & 27.16 & 5.395 \\
NW Atlantic & 61 & 7347 & 0.747 & 20.03 & 4.43 \\
NE Atlantic & 133 & 34606 & 0.761 & 27 & 5.366 \\
Nordic Seas & 18 & 1419 & 0.336 & 6.463 & 1.399 \\
\hline
\end{tabular}

this is not evident from comparison of diversities of pooled regional data (Table 6).

\section{Biodiversity pattern of Cumacea}

Expected species diversities in samples of the entire Atlantic data set showed a broadly similar curvilinear pattern (peaking at low latitudes) to that of isopods, gastropods and bivalves (Rex et al. 1993, 1997), suggesting similar controlling factors. The powerful imprint of regional history in the North Atlantic is well illustrated by the strong influence of the Nordic Seas samples on the negative relationships of $E\left(S_{50}\right)$ and $H^{\prime}$ to latitude, and the differing levels of diversity expressed on the 2 sides of the North Atlantic (Table 6, Fig. 5A,B).

The present results seem consistent with impoverished cumacean diversity in the deep Nordic Seas being caused by relatively recent glacially driven extinction (and perhaps massive submarine slides) coupled to isolation by submarine sills from the warmer deep Atlantic to the south, and its immature status of recolonisation. Causation of diversity differences in the western versus the eastern North Atlantic also may well be related to history as a result of latitudinal asymmetry in effects of Quaternary glaciation at the the continental margin.

\section{Comparison with results for other deep-sea taxa}

Overall the results for ecological diversity of Cumacea are broadly similar to the negative relationships between diversity and latitude found previously for isopods, gastropods bivalves and Foraminifera in the deep Atlantic (Rex et al. 1993, 2000, Culver \& Buzas 2000), but not to the slightly positive relationship found for nematodes (Lambshead et al. 2000). A highly significant negative relationship of ecological diversity as $E\left(S_{50}\right)$ and a weakly significant negative relation- 
ship as Shannon's $H^{\prime}$ to latitude in the eastern North Atlantic was evident even when the Nordic Seas samples were removed (Table 1, Figs. 5A,B), and this is also similar to the significant pattern showed by isopods and gastropods for the North Atlantic after removal of Nordic Seas samples (Rex et al. 1997). Our results support the latter authors in countering the claim of Gray (1994) that significant northern latitudinal gradients are entirely attributable to low diversity in the Nordic Seas.

Basin-scale diversity differences between the western and eastern North Atlantic cumaceans after removal of the Nordic Seas samples are not apparent from Rex et al.'s (1993, 1997, 2000) plotted sample diversities for molluscs and isopods in the North Atlantic, but their data points for the eastern North Atlantic were more sparse than in the present study. However, a difference between the western and eastern sides of the North Atlantic may apply at least to bivalves, since Allen \& Sanders (1997) in their comprehensive zoogeographic analysis of deep-sea protobranch bivalves remarked on the lower species richness in the North American Basin compared to the West European Basin. For the Cumacea, when the North Atlantic data are pooled, the higher diversities in the eastern North Atlantic than in the western North Atlantic are quite sufficient to counteract the significant negative relationships with latitude observed when data from the 2 sides of the Atlantic are considered separately (Fig. 5). It seems reasonable to predict that for other taxa differences caused by differing regional history may mask the effect of ecological influences such as productivity on LSDGs.

Effects of differences in lifestyle, reproduction and dispersal between taxa may be more apparent than real. Although cumacaeans and isopods both have direct development (as opposed to the more extensive larval dispersal among bivalves and gastropods) the motility of males and manca stages of Cumacea may at least enhance dispersal and be an important factor in determining large-scale biodiversity patterns through reducing isolation and allopatric speciation.

The differing pattern in nematodes compared to the macrobenthic taxa was also ascribed by Lambshead et al. $(2000,2002)$ to productivity. Fundamental bodysize-related differences determining macroecological pattern may enhance the importance of such ecological influences. Little is known of the ecological dispersal and zoogeography of meiofaunal organisms such as nematodes in the deep sea. However, the smallest size classes of aquatic organisms have wider geographic ranges (Fenchel 1993), and if they follow the pattern of deep-sea meiofaunal nematodes, also lower regional (but not local-scale) species richness (Lambshead et al. 2003) than larger organisms such as macrofaunal poly- chaetes (Glover et al. 2002). Differences in lifestyle and mode of reproductive dispersal may contribute to historical processes in determining the zoogeographic range and large-scale biodiversity pattern of macrofauna. Although specialised means for reproductive dispersal are virtually absent in meiofaunal taxa, their zoogeographic ranges are very large (Gerlach 1977, Fenchel 1978). Fenchel (1993) suggested that their vastly higher population sizes means that statistically they have much higher potential rates of dispersal, thus much reducing the risk of lasting local extinction and allopatric speciation. This would also much reduce regional-to-global-scale richness compared to that arising from local, ecological processes (such as productivity), so that the large-scale historical patterns observed in macrofauna would be less marked or absent. Impoverished nematode species richness in the Nordic Seas compared to the deep North Atlantic (Lambshead et al. 2000) may have persisted only because of the isolation of the respective water masses.

\section{Atlantic-wide zoogeographic pattern for Cumacea}

Lambshead et al. (2002) pointed out that the diversity pattern for bivalves and gastropods in the deep Atlantic reported by Rex et al. (1993), and now shown for Cumacea, is consistent with the global biodiversity pattern for molluscs described by Clarke \& Crame (1997) and Crame (2000). Broadly speaking, there are 2 'hotspots' in the equatorial Indo-West Pacific and the Eastern Pacific, with diversity declining away from these points. This gives the illusion of a classic latitudinal gradient in the North Atlantic, but not the South Atlantic, as species migrate away from these zones of speciation. It is noteworthy that younger molluscan clades show the steepest gradient (Crame 2000). It seems possible that a similar explanation might explain the isopod diversity pattern (Wilson 1998), as in general the steepest latitudinal and longitudinal gradients are associated with tropical high-diversity foci (Crame \& Rosen 2002), but this remains to be established.

In the Nematoda there is no evidence that tropical diversity is any higher than in temperate regions (Boucher \& Lambshead 1995, Lambshead \& Boucher 2003). Also, the major nematode clades show no obvious pattern of speciation in and dispersion from a specific geographical location.

The situation is essentially similar for the Cumacea: tropical foci have not been established. The deep Atlantic data also gives no evidence for coherent speciation foci for the entire taxon. The deep-sea fauna includes representatives of 7 of the 8 commonly recognised cumacean families. Of these 7,6 are also strongly represented on the shelf; thus most deep-sea species 
have close (congeneric or at least confamilial) relatives in shallow waters. The seventh family, the Ceratocumatidae, is small and overwhelmingly deep-water, the exception being 1 species described from $196 \mathrm{~m}$ depth off Kerguelen, India. (The remaining cumacean family, the Gynodiastylidae, is Indo-West Pacific in distribution and restricted to shallow water, except for 1 species recorded down to $680 \mathrm{~m}$ off SE Africa.)

It is debatable, therefore, whether the deep sea or shallow water has been the centre of radiation or indeed if there has been a consistent centre for the clades; however, given the relative ages of deep-sea and shallow-water cumacean faunas, parsimony suggests the latter (Jacobs \& Lindberg 1998 and references therein). Limited evidence for Atlantic endemism comes from moderately diverse genera such as the nannastacids Platycuma and Styloptocuma (the latter often regarded as a subgenus of Cumella) that are recorded only from the deep Atlantic, but it is possible that this merely reflects the greater taxonomic effort to date in the Atlantic.

There were more species revealed by the asymptotic richness curves than predicted by the ICE in the regional diversity estimations (Table 6). This might suggest that there are few undiscovered cumacean species in the Atlantic (cryptics aside) and that our data is more adequate and representational than, for example, nematode data. Nevertheless, we know that many species are unrepresented in the data set because they have not yet been described. Therefore the ICE estimates could be biased; certainly, the method is less statistically constrained than the estimate of asymptotic richness curves. A similar underestimation compared to extrapolation was found in comparisons of nematode species richness by Lambshead et al. (2003), who cited work by Ellingsen \& Gray indicating that such nonparametric estimators may underestimate the true value by as much as $100 \%$.

However, overall the data do not support a molluscan or isopod-type pattern of dispersion of species entering from the south and moving up through the Atlantic to north. The eastern Atlantic is somewhat richer than the west, but this is because the western North Atlantic is impoverished compared to the other 2 regions. Why this should be so is unclear but may be related to asymmetry in the intensity of glacial effects at the continental margin on the 2 sides of the North Atlantic.

Examination of unique species also gives no support to the idea of a centre of dispersion. Except for the zero value for the Nordic Seas, the number of unique species in each region is reasonably close to the number predicted for each region as a proportion of sampling intensity (number of samples). The low values of the Bray-Curtis percent similarity (range 1.20 to 9.66) on which the analysis of similarities (ANOSIM) is based contrast with this and may suggest that cumacean species are not particularly wide-ranging. However, a more likely explanation is that the regions remain under-sampled.

Although the sample number on which our estimate was based was small, the lack of species unique to the Nordic Seas is noteworthy: its limited cumacean fauna are all found elsewhere in the deep Atlantic. This supports a hypothesis of geologically recent recolonisation after a catastrophic event. There is evidence that largescale gradients associated with latitude have not always existed to the same degree. They have increased markedly throughout the Cenozoic area and are associated with the phenomenon of global climate change, especially the switch from a warm world to an ice world (Culver \& Buzas 2000, Crame 2001, 2002, Crame \& Rosen 2002). The present patterns are therefore not an eternal feature and are unlikely to survive further climate change.

\section{Conclusions}

Our results do not support classical latitudinal gradients in Cumacea in the terrestrial sense of single structuring solar-linked processes (Crame \& Clarke 1997, Lambshead et al. 2002). A variety of patterns seems to exist for different taxa, suggesting a causal balance between history and ecological processes related to body size and possibly lifestyle. For the macrofauna, the molluscan (and possibly isopod) diversity pattern is consistent with an hypothesis of dispersion from highdiversity foci in the tropics along the latitudinal productivity gradient, whereby increasing seasonality that depresses diversity (possibly by decreasing evenness) plays a supporting role. In cumaceans, productivity may also have a similar effect, but patterns are obscured in the North Atlantic by differing regional histories. In meiofauna, the imprint of history appears less important and is perhaps absent. In nematodes, the effect of the productivity gradient is to increase diversity by increasing population size. Foraminifera, which show a consistent latitudinal diversity pattern in both northern and southern hemispheres, are controlled by the productivity gradient in the same way as macrofauna. However, Foraminifera lack an imprint of history except in terms of the climatic change 36 million yr ago which led to seasonally fluctuating food supplies at higher latitudes.

A consistent feature across all these major taxa is that low diversity in the deep Nordic Seas is a regional phenomenon and not part of a large-scale latitudinal pattern (Svavarsson 1997). This, combined with the diversity differences observed between the western and eastern North Atlantic, reminds us that the large- 
scale biodiversity pattern of macrofauna, but not nematodes, in the deep ocean probably reflects as much regional history as modern ecology.

Acknowledgements. J.D.G thanks Dr. Bhavani Narayanaswamy for help with SigmaPlot software and J.D.G. and J.D.D.B. thank Dr. Salma Shalla at Port Erin Marine Laboratory for help in accessing station details and data in N.S.J.'s notebooks.

\section{LITERATURE CITED}

Abrams P (1995) Monotonic or unimodal diversity-productivity gradients: what does competition theory predict? Ecology 76:2019-2027

Allen JA (1978) Evolution of the deep-sea protobranch bivalves. Philos Trans R Soc Lond B 284:387-401

Allen JA, Sanders HL (1997) The zoogeography, diversity and origin of the deep-sea protobranch bivalves of the Atlantic: the epilogue. Prog Oceanogr 38:95-153

Aller JY (1997) Benthic community response to temporal and spatial gradients in physical disturbance within a deepsea western boundary region. Deep-Sea Res 44:39-69

Angel MA (1993) Biodiversity of the pelagic ocean. Conserv Biol 7:760-772

Bishop JDD, Shalla SH (1994) Discrete seasonal reproduction in an abyssal peracarid crustacean. Deep-Sea Res 41: 1789-1800

Bond G, Lotti R (1995) Iceberg discharges into the North Atlantic on millennial time scales during the last glaciation. Science 267:1005-1010

Boucher G, Lambshead PJD (1995) Ecological biodiversity of marine nematodes in samples from temperate, tropical, and deep-sea regions. Conserv Biol 9:1594-1604

Bouchet P, Warén A (1980) Revision of the North-East Atlantic bathyal and abyssal Turridae (Mollusca, Gastropoda). J Molluscan Stud Suppl 8:1-119

Bromham L, Cardillo M (2003) Testing the link between the latitudinal gradient in species richness and rates of molecular evolution. J Evol Biol 16:200-207

Bugge T, Belderson RH, Kenyon NH (1988) The Storrega slide. Philos Trans R Soc Lond A 325:357-388

Cartes JE, Sorbe JC (1996) Temporal population structure of deep-water cumaceans from the western Mediterranean slope. Deep-Sea Res 43:1423-1438

Cartes JE, Sorbe JC (1997) Bathyal cumaceans of the Catalan Sea (north-western Mediterranean): faunistic composition, diversity and near-bottom distribution along the slope (between 389 and 1859 m). J Nat Hist 31:1041-1054

Chazdon RS, Colwell RK, Denslow JS, Guariguata MR (1998) Statistical methods for estimating species richness of woody regeneration in primary and secondary rain forests of northeastern Costa Rica. In: Dallmeier F, Comiskey JA (eds) Forest biodiversity research, monitoring and modelling. UNESCO, Parthenon Publishing Group, Paris, p 285-309

Clarke A, Crame JA (1997) Diversity, latitude and time: patterns in the shallow sea. In: Ormond RFG, Gage JD, Angel MV (eds) Marine biodiversity. Cambridge University Press, Cambridge, p 122-147

Clarke KR (1993) Non-parametric multivariate analyses of changes in community structure. Aust J Ecol 18:117-143

Corbera J (2000) Systematics and distribution of cumaceans collected during BENTART-95 cruise around South Shetland Islands (Antarctica). Sci Mar 64:9-28
Crame JA (2000) Evolution of taxonomic diversity gradients in the marine realm: evidence from the composition of Recent bivalve faunas. Paleobiology 26:188-214

Crame JA (2001) Taxonomic diversity gradients through geological time. Divers Distrib 7:175-189

Crame JA (2002) Evolution of taxonomic diversity gradients in the marine realm: a comparison of late Jurassic and recent bivalve faunas. Paleobiology 28:184-207

Crame JA, Clarke A (1997) The historical component of marine taxonomic diversity gradients. In: Ormond RFG, Gage JD, Angel MV (eds) Marine biodiversity. Cambridge University Press, Cambridge, p 258-273

Crame JA, Rosen BR (2002) Cenozoic paleogeography and the rise of modern biodiversity patterns. In: Crame JA, Owen Aw (eds) Paleobiogeography and biodiversity change: the Ordovician and Mesozoic-Cenozoic radiations. Geological Society, London, p 153-168

Cronin TM, Raymo ME (1997) Orbital forcing of deep-sea benthic species diversity. Nature 385:624-627

Culver SJ, Buzas MA (2000) Global latitudinal species diversity gradient in deep-sea benthic Foraminifera. Deep-Sea Res I 47:259-275

Dahl E (1972) The Norwegian Sea deep water fauna and its derivation. Ambio Spec Rept 2:19-24

Dauvin JC, Kendall M, Paterson G, Gentil F, Jirkov I, Sheader $M$ (1994) An initial assessment of polychaete diversity in the northeastern Atlantic Ocean. Biodiv Lett 2:171-181

Dodge JD, Marshall HG (1994) Biogeographic analysis of the armoured planktonic dinoflagellate Ceratium in the North Atlantic and adjacent seas. J Phycol 30:905-922

Ellingsen KE, Gray JS (2002) Spatial patterns of benthic diversity; is there a latitudinal gradient along the Norwegian continental shelf? J Anim Ecol 71:373-389

Etter RJ, Mallineaux LS (2000) Deep-sea communities. In: Bertness MD, Gaines SD, Hay ME (eds) Marine community ecology. Sinauer Associates, Sunderland, MA, p 367-393

Fenchel T (1978) The ecology of micro- and meiobenthos. Annu Rev Ecol Syst 9:99-121

Fenchel $T$ (1993) There are more small than large species? Oikos 68:375-370

Fischer AG (1960) Latitudinal variations in organic diversity. Evolution 14:64-81

Flach E, de Bruin W (1998) Diversity patterns in macrobenthos across a continental slope in the NE Atlantic. J Sea Res 42:303-323

Gage JD (1975) A comparison of the deep-sea epibenthic sledge and anchor-box dredge samplers with the van Veen grab and hand coring by diver. Deep-Sea Res 22: 695-702

Gage JD (1996) Why are there so many species in deep-sea sediments? J Exp Mar Biol Ecol 200:257-286

Gage JD, Tyler PA (1991) Deep-sea biology: a natural history of organisms at the deep-sea floor. Cambridge University Press, Cambridge

Gage JD, Lightfoot RH., Pearson M, Tyler PA (1980) An introduction to a sample time-series of abyssal macrobenthos: methods and principle sources of variability. Oceanol Acta 3:169-176

Gage JD, Lamont PA, Tyler PA (1995) Deep-sea macrobenthic communities at contrasting sites off Portugal, preliminary results. I. Introduction and diversity comparisons. Int Rev Ges Hydrobiol 80:235-250

Gage JD, Lamont PA, Kroeger K, Paterson GLJ, Gonzales Vecino JL (2000) Patterns in deep-sea macrobenthos at the continental margin: standing crop, diversity and faunal change on the continental slope off Scotland. Hydrobiologia 440:261-271 
Gaines SD, Lubchenco J (1982) A unified approach to marine plant-herbicide interactions. II. Biogeography. Annu Rev Ecol Syst 13:111-138

Gaston KJ (2000) Global patterns in biodiversity. Nature 405: 220-227

Gerlach SA (1977) Means of meiofauna dispersal. Mikrofauna Meeresbod 61:89-103

Glover AG, Paterson GLJ, Bett B, Gage J, Sibuet M, Sheader M, Hawkins L (2001) Patterns in polychaete abundance and diversity from the Madeira Abyssal Plain, north-east Atlantic. Deep-Sea Res 48:217-236

Glover AG, Smith CR, Paterson GLJ, Wilson GDF, Hawkins L, Sheader M (2002) Polychaete species diversity in the central Pacific abyss: local and regional patterns, and relationships with productivity. Mar Ecol Prog Ser 240:157-170

Gooday AJ (1988) A response by benthic Foraminifera to the deposition of phytodetritus in the deep sea. Nature 332: $70-73$

Gooday AJ, Lambshead PJD (1989) Influence of seasonally deposited phytodetritus on benthic foraminiferal populations in the bathyal northeast Atlantic: the species response. Mar Ecol Prog Ser 58:53-67

Gotelli NJ, Colwell RK (2001) Quantifying biodiversity: procedures and pitfalls in the measurement and comparison of species richness. Ecol Lett 4:379-391

Grassle JF, Maciolek NJ (1992) Deep sea species richness: regional and local diversity estimates from quantitative bottom samples. Am Nat 139:313-341

Gray JS (1994) Is deep-sea biodiversity really so high? Species diversity of the Norwegian continental shelf. Mar Ecol Prog Ser 112:205-209

Gray JS (1997) Gradients in marine biodiversity. In: Ormond RFG, Gage JD, Angel MV (eds) Marine biodiversity. Cambridge University Press, Cambridge, p 18-34

Gray JS (2002) Species richness of marine soft sediments. Mar Ecol Prog Ser 244:285-297

Gray JS, Poore GCB, Ugland KI, Wilson RS, Olsgard F, Johannessen $\varnothing$ (1997) coastal and deep-sea benthic diversities compared. Mar Ecol Prog Ser 159:97-103

Hawkins BA, Field R, Cornell HV, Currie DJ and 8 others (2003) Energy, water, and broad-scale geographic patterns of species richness. Ecology 84:3105-3117

Hessler RR, Sanders HL (1967) Faunal diversity in the deep sea. Deep-Sea Res 14:65-78

Hicks RF, Coull BC (1983) The ecology of marine meiobenthic harpacticoid copepods. Oceanogr Mar Biol Annu Rev 21: $67-175$

Hillebrand H, Azovsky AI (2001) Body size determines the strength of the latitudinal gradient. Ecography 24:251-256

Hurlbert SH (1971) The non-concept of species diversity: a critique and alternative parameters. Ecology 52:577-586

Jacobs, DK, Lindberg DR (1998) Oxygen and evolutionary patterns in the sea: onshore/offshore trends and recent recruitment of deep-sea faunas. Proc Natl Acad Sci USA 95:9396-9401

Jones NS (1976) British cumaceans. Synopses Br Fauna 7: $1-66$

Jones NS (1985) Distribution of the Cumacea. In: Laubier L, Monniot C (eds) Peuplements profonds du Golfe de Gascogne. Institut Français de recherché pour l'Exploitation de la Mer, Brest, p 419-424

Jones NS, Sanders HL (1972) Distribution of Cumacea in the deep Atlantic. Deep-Sea Res 19:737-745

Jumars PA, Hessler RR (1976) Hadal community structure: implications from the Aleutian Trench. J Mar Res 34:547-560

Kendall MA, Aschan M (1993) Latitudinal gradients in the structure of macrobenthic communities: a comparison of
Arctic, temperate and tropical sites. J Exp Mar Biol Ecol 172:157-169

Lambshead PJD (1993) Recent developments in marine benthic biodiversity research. Océanis 19:5-24

Lambshead PJD, Boucher G (2003) Marine nematode deepsea biodiversity-hyperdiverse or hype? J Biogeogr 30: 475-485

Lambshead PJD, Gooday AJ (1990) The impact of seasonally deposited phytodetritus on epifaunal and shallow infaunal benthic foraminiferal populations in the bathyal northeast Atlantic: the assemblage response. Deep-Sea Res 37: 1263-1283

Lambshead PJD, Tietjen J, Ferraro T, Jensen P (2000) Latitudinal diversity gradients in the deep sea with special reference to North Atlantic nematodes. Mar Ecol Prog Ser 194:159-167

Lambshead, PJD, Tietjen J, Moncrieff CB, Ferraro TJ (2001a) North Atlantic latitudinal diversity patterns in deep-sea marine nematode data: a reply to Rex et al. Mar Ecol Prog Ser 210:299-301

Lambshead PJD, Tietjen J, Glover A, Ferrero T, Thistle D, Gooday A (2001b) The impact of large-scale natural physical disturbance on the diversity of deep-sea North Atlantic nematodes. Mar Ecol Prog Ser 214:121-1264

Lambshead PJD, Brown CJ, Ferraro TJ, Mitchell NJ, Smith CR, Hawkins LE, Tietjen J (2002) Latitudinal diversity patterns of deep-sea marine nematodes and organic fluxes: a test from the central equatorial Pacific. Mar Ecol Prog Ser 236:129-135

Lambshead PJD, Brown CJ, Ferrero T, Mitchell N, Hawkins LE, CR Smith (2003) Biodiversity of nematode assemblages from the Clarion-Clipperton fracture zone, an area of commercial mining interest. BMC Ecol 3:1

Lee SM, Chao A (1994) Estimating population size via sample coverage for closed capture-recapture models. Biometrics 50:88-97

Levin LA, Gage JD (1998) Relationships between oxygen, organic matter and the diversity of bathyal macrofauna. Deep-Sea Res II 45:129-163

Levin LA, Etter RJ, Rex MA, Gooday AJ, Smith CR and 5 others (2001) Environmental influences on regional deep-sea species diversity. Annu Rev Ecol Syst 32:51-93

Lowe JJ, Walker MJC (1997) Reconstructing Quaternary environments. Pearson Longman, Harlow, UK

Macpherson E (2002) large-scale species-richness gradients in the Atlantic Ocean. Proc R Soc Ser B 95:3699-3702

Magurran AE (1988) Ecological diversity and its measurement. Princeton University Press, Princeton, NJ

McGowan JA, Walker PW (1993) Pelagic diversity patterns. In: Ricklefs RE, Schluter D (eds) Species diversity in ecological communities: historical and geographical perspectives. Chicago University Press, Chicago, p 203-214

Mittelbach GG, Steiner CF, Scheiner SM, Gross KL and 5 others (2001) What is the observed relationship between species richness and productivity? Ecology 82:2381-2396

Mokievsky V, Azovsky A (2002) Re-evaluation of species diversity patterns of free-living marine nematodes. Mar Ecol Prog Ser 238:101-108

Paterson GLJ, Lambshead PJD (1995) Bathymetric patterns of polychaete diversity in the Rockall Trough, north-east Atlantic. Deep-Sea Res 42:1199-1214

Poore GCB, Wilson GDF (1993) Marine species richness. Nature 361:597-598

Reid JL, Brinton E, Fleminger A, Venrik EL, McGowan JA (1978) Ocean circulation and marine life. In: Charnock H, Deacon G (eds) Advances in oceanography. Plenum Press, New York, p 65-130 
Rex MA (1981) Community structure in the deep-sea benthos. Annu Rev Ecol Syst 12:331-353

Rex MA (1983) Geographic patterns of species diversity in the deep-sea benthos. In: Rowe GT (ed) The seas, Vol 8. J. Wiley, New York, p 453-472

Rex MA, Stuart CT, Hessler RR, Allen JA, Sanders HL, Wilson GDF (1993) Global-scale latitudinal patterns of species diversity in the deep-sea benthos. Nature 365:636-639

Rex MA, Etter RJ, Stuart CT (1997) Large-scale patterns of species diversity in the deep-sea benthos. In: Ormond RFG, Gage JD, Angel MV (eds) Marine biodiversity: patterns and processes. Cambridge University Press, Cambridge, p 94-121

Rex MA, Stuart CT, Coyne G (2000) Latitudinal gradients of species richness in the deep-sea benthos of the North Atlantic. Proc Natl Acad Sc USA 97:4082-4085

Rex MA, Stuart CT, Etter RJ (2001) A comment on whether deep-sea nematodes show a positive latitudinal gradient of species diversity: the potential role of depth. Mar Ecol Prog Ser 210:297-298

Rice AL, Aldred RG, Darlington E, Wild RA (1982) The quantitative estimation of the deep-sea megabenthos: a new approach to an old problem. Oceanol Acta 5:63-72

Rohde K (1992) Latitudinal gradients in species diversity: the search for the primary cause. Oikos 65:514-527

Rosenzweig ML (1995) Species diversity in space and time. Cambridge University Press, Cambridge

Rosenzweig ML, Abramsky Z (1993) How are diversity and productivity related? In: Ricklefs RE, Schluter D (eds) Species diversity in ecological communities. University of Chicago Press, Chicago, p 52-65

Rowe MA (1980) The unsuitability of species-diversity indexes for describing a latitudinal gradient. Am Zool 20:917

Roy K, Jablonski D, Valentine JW (1994) Eastern Pacific molluscan provinces and latitudinal diversity gradient-no evidence for Rapoport's rule. Proc Natl Acad Sci USA 91: 8871-8874

Roy J, Jablonski D, Valentine JW, Rosenberg G (1998) Marine latitudinal diversity gradients: tests of causal hypotheses. Proc Natl Acad Sci USA 95:3699-3702

Sanders HL (1969) Marine benthic diversity and the stabilitytime hypothesis. Brookhaven Symp Biol 12:71-81

Shaw KM, Lambshead PJD \& Platt HM (1983) Detection of pollution-induced disturbance in marine benthic assemblages with special reference to nematodes. Mar Ecol Prog Ser 11:195-202

Editorial responsibility: Otto Kinne (Editor), Oldendorf/Luhe, Germany
Snelgrove PVR, Smith CR (2002) A riot of species in an environmental calm: the paradox of the species-rich deep-sea floor. Oceanogr Mar Biol Annu Rev 40:311-342

Stehli FG, McAlester AL, Helsley CE (1967) Taxonomic diversity of recent bivalves and some implications for geology. Geol Soc Am Bull 78:455-466

Svavarsson, J (1997) Diversity of isopods (Crustacea): new data from the Arctic and Atlantic Oceans. Biodiv Conserv 6:1571-1579

Svavarsson J, Stromberg JO, Brattegard T (1993) The deepsea asellote (Isopoda, Crustacea) fauna of the Northern Seas: species composition, distributional patterns and origins. J Biogeogr 20:535-537

Thistle D, Yingst JY, Fauchald K (1985) A deep-sea benthic community exposed to strong bottom currents on the Scotian Rise (Western Atlantic). Mar Geol 66:91-112

Thomas E, Gooday AJ (1996) Cenozoic deep-sea benthic foraminifers: tracers for changes in oceanic productivity. Geology 24:355-358

Thorson G (1950) Reproduction and larval ecology of marine bottom invertebrates. Biol Rev 25:1-45

Thorson G (1957) Bottom communities (sublittoral or shallow shelf). In: Hedgepeth JW (ed) Treatise on marine ecology and paleoecology. Geological Society of America, New York, p 461-534

Vetter EW, Dayton PK (1998) Macrofaunal communities within and adjacent to a detritus-rich canyon system. Deep-Sea Res II 45:25-54

Waide RB, Willig MR, Steiner CF, Mittelbach G, Gough L, Dodson SI, Joday GP, Parmenter R (1999) The relationship between productivity and species richness. Annu Rev Ecol Syst 30:257-300

Wallace AR (1878) Tropical nature and other essays. MacMillan, London

Warwick RM, Ruswahyuni (1987) Comparative study of the structure of some tropical and temperate marine soft-bottom macrobenthic communities. Mar Biol 95: 641-649

Willig MR, Kaufman DM, Stevens RD (2003) Latitudinal gradients of biodiversity: pattern, process, scale, and synthesis. Annu Rev Ecol Evol Syst 34:273-309

Wilson GDF (1998) Historical influences on deep-sea isopod diversity in the Atlantic Ocean. Deep-Sea Res II 45: 279-301

Wilson GDF, Hessler RR (1987) Speciation in the deep sea. Annu Rev Ecol Syst 18:185-207

Submitted: September 18, 2003; Accepted: April 8, 2004

Proofs received from author(s): July 30, 2004 